\title{
Aligning Product Variety with Supply Chain and Business Strategy
}

\author{
Juneho Um $\mathrm{a}^{\mathrm{a}^{*}}$

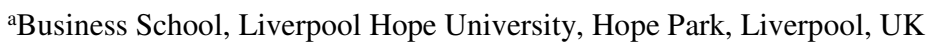 \\ juno9782@ hotmail.com \\ Phone:+44 01512913072 \\ * First and Corresponding author \\ Neungho $\operatorname{Han}^{\mathrm{b}}$ \\ ${ }^{\mathrm{b}}$ Institute of Foreign Trade Research Units, Sungkyunkwan University, Seoul, South Korea \\ nhhan@skku.edu \\ Tonci Grubic ${ }^{\mathrm{c}}$ \\ 'Business School, Liverpool Hope University, Hope Park, Liverpool, UK \\ grubict@hope.ac.uk \\ Asad Ghalib ${ }^{\mathrm{d}}$ \\ ${ }^{\mathrm{d}}$ Business School, Liverpool Hope University, Hope Park, Liverpool, UK \\ ghaliba@hope.ac.uk
}

\begin{abstract}
Purpose - The study aims to demonstrate the strategic alignment between product variety and supply chain focus through cost leadership or differentiation to improve business performance.

Design/methodology/approach - The research investigated product variety-related capabilities and strategies in supply chains including level of variety, supply chain agility, supply chain cost efficiency, cost leadership, differentiation and business performance, and aimed to justify the theory by testing structural equation modelling using survey data from the UK and South Korea.

Findings - Differentiation links high product variety and agile supply chain while cost leadership is aligned with low product variety and supply chain efficiency. High product variety negatively impacts on cost leadership strategy. Also, product variety should be mediated by cost leadership or differentiation strategy to improve business performance. Companies in South Korea display higher supply chain agility, cost leadership and cost efficiency than companies in the UK, while the UK companies exhibit a higher level of product variety and differentiation than those in South Korea.
\end{abstract}

Research implications - The findings contribute to theoretical development of variety issues at the alignment of business strategy and supply chain management according to the level of product variety.

Originality/value - The findings can help international companies set up specific variety-related strategies to achieve global competitiveness.

Keywords - Product variety, Supply chain, Business performance, Structural equation modelling Paper type - Research paper 


\section{Introduction}

Globalisation promotes the need to customise products and services according to the target market or country, and provision of product scope is an issue in deciding if globalisation raises marginal variety's profit (Qiu and Zhou, 2013). Deregulation of trade with supporting technologies has promoted global markets, so manufacturers are required to appropriate strategies in order to provide product variety to different markets. In addition, a noticeable movement for manufacturers is to extend the variety of their products to provide more options for customers in today's challenging global markets. Consumers can match their needs and preferences with the product variety provided by manufacturers (Lancaster, 1990). For example, mega-stores such as Tesco and Wal-Mart provide wide product variety in their quest to provide value to consumers, enabling the stores to improve market share and revenue. Some researchers stress the advantages of product variety based on long-tail theory (Anderson, 2006; Zhou and Duan, 2012), that product variety can improve sales, while others criticise high levels of variety provision mainly due to cost increase. Also, an excess of product information and provision can result in selection confusion for customers and lead to forecasting difficulty for manufacturers (Wan et al., 2012). For example, the market share of Aldi keeps growing, focusing on cost leadership with low product variety, while Tesco have lost their market share to an increasing number of low-cost providers. From the operations perspective, an increase in product variety incurs a cost burden due to diseconomies of scale in the supply chain (SC). The emergence of a global SC has detonated the trade-off between provision of product variety and supply chain performance. Increases in product variety in the global SC incur both production costs and market mediation costs (Randall and Ulrich, 2001). Also, global purchasing and logistic costs increase with product variety provision. High-variety ambitions need to be 
profitably achieved without severe deterioration of SC performance, especially considering the cost profile.

Many manufacturers have recognised that a trade-off exists between product variety and SC performance (Fisher and Ittner, 1999; Thonemann and Bradley, 2002; Um et al., 2017). Thus several researchers (Yeh and Chu, 1991; Blecker and Abdelkafi, 2006; Scavarda et al., 2010; Patel and Jayaram 2013) have investigated how to mitigate the impact of product variety on the cost profile of SC processes. Modularity, cellular manufacturing and postponement, typical of functional-level management such as SC integration (Scavarda et al., 2010: Um et al., 2017), SC flexibility and agility are essential in responding quickly to diverse customer needs and improving cost efficiency (Fisher et al., 1999; Swafford et al., 2008). Supply chain flexibility and agility-based management activities in particular have been emphasised to satisfy their high-variety provisions and ambition (Um et al., 2017). In addition, partnerships with suppliers (Tummala et al., 2006; Cousins et al., 2011) and close customer relationships (Child et al., 1991; Wang and Feng, 2012) can be requisite criteria when the manufacturer considers a high level of product variety or the introduction of new products. Thus, business performance such as sales growth and SC performance including cost efficiency and customer service are influenced by the level of product variety provision and focused strategies such as cost leadership or differentiation by individual manufacturers. Theoretically, a high level of product variety environment employs a differentiation strategy to enhance customer service, while a low level of product variety environment considers the cost leadership policy resulting in cost efficiency (see Agarwal et al., 2006; Stavrulaki and Davis, 2010). However, most of the empirical studies on the relationship between product variety and business performance have dealt with potential mitigation strategies or functional approaches without explicitly 
considering the strategic alignment of supply chain and business strategies involved with product variety issues.

The level of the existing product variety reflects the organisation's strategic goals and movement. Therefore, all variety-related management capabilities including customisation (i.e. from make to stock to design to order), cost leadership and differentiation, and performance including SC cost efficiency, agility and business-related performance, can differ according to the different level of product variety provided by manufacturers. Also, variation is extended to the national level based on the theoretical approaches in managing variety concerns. The fundamental question relates the matching level of variety offered with organisational or national focus and its reflective strategies. For example, based on the product types (Fisher, 1997) or level of customisation and product variety (Agarwal et al., 2006; Stavrulaki and Davis, 2010), manufacturers are required to focus on either lean, agile or leagile supply chains (Lee, 2002).

The main objective of this study is to explore the appropriate alignment of product variety with business and SC strategy. Then, the research tests findings by comparing the differences between UK and Korean manufacturers in the level of product variety, management strategies and performance. The study also explores the structural process to achieve better business performance. This is achieved by evaluating differences in the level of variety and variety-related strategies including cost leadership and differentiation, and performance including SC agility and cost efficiency. Inspired by literature reviews on product variety and SC performance-related research (see Porter, 1977; Randall and Ulrich, 2001; Stavrulaki and Davis, 2010; Agarwal et al., 2013), the study also examines how differences in product variety between the UK and Korea influence SC strategies and performance from global perspectives. The UK and Korea have different economic backgrounds and outputs, such as economic growth rates (i.e. 1.8 vs. $2.8 \%$ ), GDPs (i.e. 
2,868 vs. 1,147 billion \$), trade volume (i.e. 674 vs. 527 billion \$ in exports), inflation rates (i.e. 1.8 vs. $1.1 \%$ ) and income distribution (i.e. 0.32 vs. 0.30 in Gini coefficient) (International Monetary Fund, 2016; Central Intelligence Agency, 2016). Therefore, the data was collected from two countries that have different economic backgrounds for a cross-examination to generalise the research outcomes better in the global business environment. The key aims for this study are to identify: 1) appropriate alignment of business strategies with product variety in the supply chain; 2) the relationships between variety-related factors responsible for improving business performance; and 3) the differences in product variety, and supply chain performance, that exist between the UK and Korea, suggesting the appropriate supply chain implications for companies in each country.

The research makes two significant contributions. First, it establishes the relative extended theory of product variety management at corporation and national level. A corollary of this contribution concerns the subsequent implications for company strategies and policy. Secondly, the research findings from manufacturers explain how different levels of product variety can impact on business performance positively within the SC. The findings also suggest important managerial and practical alignment for the adoption of different approaches to product variety under different strategic backgrounds, from the perspective of manufacturers.

\section{Research background and development of hypotheses}

\subsection{Product variety and supply chain performance}

The term 'product variety' is employed by academics and industry with a number of different conceptual meanings (Stablein, Holweg and Miemczyk, 2011). Thus the concept and scope of product variety must be defined clearly. For example, variety can be defined 
as a number or collection of different things of a particular class of the same general kind, and product line breadth refers to the stock-keeping units (SKUs) within a brand category. (Elmaraghy et al., 2013). Therefore, increase in product variety refers to the introduction of new products and can be calculated as the number of Stock Keeping Units (SKUs) in the supply chain (Wan et al., 2012). MacDuffie, Sethuraman and Fisher (1996) and MacDuffie et al. (1997) defined it to refer to company choices about the breadth and depth of different product lines using three dimensions for types of variety: 1) fundamental (i.e. different core models and designs at the fabrication and design stage), 2) intermediate (i.e. different technical options dependent on core design at the assembly stage), and 3) peripheral (i.e. particular options and accessories independent of core design at the distribution and sales stage). Such an explanation is a reference to internal variety that is generally regarded as the variance involved in creating the product within a firm or SC. On the other hand, external variety is the extent of different and distinguishable products offered by manufacturers in the marketplace that is available to the end consumers. This study employed internal variety based on the concept of MacDuffie et al. (1997) from the perspective of manufacturers, considering potential varieties the manufacturers are able to provide.

There is a robust relationship between product variety and the SC cost escalation (Scavarda et al., 2010). A more cost-efficient provision of product variety can generally be attained through three operations strategies: 1) use of the modularity concept by changes in product architecture, which can result in minimising the complexity and associated cost in SC functions (see Forza and Salvador, 2002; Holweg and Pil, 2004; Caridi et al., 2012); 2) flexibility in the operations process using group technology (see Child et al., 1991; Berry and Cooper, 1999); and 3) postponement strategy which delays product configuration decisions in the SC process, such as form and time postponement (Holweg and Helo, 
2014). However, since functional-level strategies suggested do not cover the entire SC, the level of product variety should be matched with organisational SC strategies in advance. For example, stock-outs that result from a high product variety strategy may ultimately hurt sales performance (Wan et al., 2012).

Beamon (1999) developed a SC performance framework through a mixture of measures, and suggested three systemic types of performance as critical components: resource, output and flexibility. The resource measure refers to a high level of SC efficiency (e.g. the total costs of resources, inventory, manufacturing, distribution in the supply chain) while the output measure refers to a high level of customer service (e.g. customer satisfaction, customer response times, on-time deliveries, order fill rate, customer complaints, backorder/stock-out, manufacturing lead time, and shipping errors). Many organisations are endeavouring to capture the benefits of flexibility in supply chains (Gopal and Thakkar, 2012). Supply chain flexibility is the internal capability for responding to the changing environment at the functional level. Its attributes are three fundamental processes: procurement, manufacturing and distribution flexibility (Swafford et al., 2006). However, agility represents an externally focused competence concentrating more on speed at the business level, such as market responsiveness, delivery reliability, lead time, product customisation and frequency of product introduction (Swafford et al., 2008). Therefore, supply chain flexibility such as change delivery time, production volume, production mix, delivery schedule and implementation of emerging change can be regarded as an important antecedent of SC agility. Agility itself is a dynamic capability concerned with speed in unpredictable markets with significant demand turbulence to achieve better customer service. Therefore, the role of SC agility should be stressed in the high product variety environment. This study adapts the concept of SC cost efficiency from Beamon (1999) and SC agility from Swafford et al. (2008) respectively. 


\subsection{Research model and hypotheses}

Theorising seeks to produce findings grounded in evidence and geared toward understanding how relations lead to results, and it extends knowledge (Theodore et al., 2017). One obvious piece of evidence is that product variety and provision of customer options have developed for companies to increase sales volume and market share; however, companies need to accept cost increase in SC and employ appropriate SC strategies to mitigate the impact of product variety. In short, based on the level of product variety, SC strategy and competitive criteria can differ between manufacturers, which can impact on business performance differently. For example, different levels of product variety compared with competitors can result in different strategies, such as different degrees of focus on either cost leadership, differentiation or hybrid strategies. Product customisation is a factor which increases product variety (Silveria, 1998) that can have a negative impact on cost leadership (Um et al., 2017). A high product variety environment typically has unpredictable demand, short life cycle, close customer relationship and high margin (Fisher et al. 1977; Stavrulaki and Davis, 2010). Thus, focus should be on SC agility, differentiation and customer service (Um, 2017). Instead, a low product variety environment has more predictable demand, close supplier relationship and mass production (e.g. economy of scale) focusing on SC cost efficiency and cost leadership.

Cost leadership is related to cost reduction as a market winner, and differentiation is related to new product development or variety increase with high quality (Kim. 2006). Hallgren and Olhager (2009) insisted that the three strategies of Poter (2004) can fundamentally be reduced to two, since the company must choose between cost leadership and differentiation strategies even with a focused strategy. In this study, cost leadership has two elements: low price and low manufacturing unit cost. Differentiation has three 
components that are related to customer service (i.e. product), technology, and marketing differentiation respectively. For example, deliver a high quality product with volume flexibility, develop a new product quickly with design flexibility, and control the sales and distribution network with a distinctive brand image (see Kim. 2006; Hallgren and Olhager. 2009). Capabilities such as agility and cost efficiency contribute positively to business performance, either acting alone or in concert with other capabilities (Rosenzweig et al.. 2003). The variety-related characteristics in SC are summarised in Table 1.

\section{Table 1. General characteristics of product variety in supply chain}

Hypotheses 1-1 to 1-2 were designed to investigate strategic differences and performance according to the level of product variety. In terms of alignment of product variety with the strategies, the research considered SC agility, SC cost efficiency, differentiation, cost leadership and business performance. The performance of a SC can be attributed to a match or mismatch between the type of product (i.e. innovative or functional) and the design of the SC (Fisher, 1977). Stavrulaki and Davis (2010) also highlighted alignment between the key aspects of a product including product variety, and its SC processes and strategy. From the perspective of variety, a high level of product variety corresponding with a high level of customisation typically focuses on differentiation, variety management strategies and customer relationships that enhance SC agility, while a low level of product variety corresponding with a low level of customisation generally focuses on cost leadership and cost efficiency. Also, based on the long-tail effect, the change in the consumption pattern when more niche products are being provided enables demand to shift from the hits to the niches over time, which can improve customer service and satisfaction (Anderson, 2006; Zhou and Duan, 2012). Thus, the study 
proposes the strategic alignment matching strategies with product variety and the SC, shown in Figure 1 (the strategic alignment model) and the following hypotheses:

Hypothesis 1-1: High product variety is associated with increased focus on differentiation.

Hypothesis 1-2: Supply chain agility is associated with increased focus on differentiation.

\section{Figure 1. Strategic alignment model with product variety in SC}

Cost efficiency is dominant for mass production systems with a low level of customisation and variety, while more enhanced customer service is required for companies where product variety matters (see Agarwal et al., 2006). Therefore, business strategies should be considered in line with the level of product variety and SC strategies. According to Silveira (1998), the most significant factors motivating an increase in product variety are the ability to customise the product and the demands made by customers. In short, product proliferation and variety increase together (Hu et al., 2011). Under this circumstance an agile system is appropriate for differentiation that focuses on product variety and customisation and is negatively associated with a cost-leadership strategy that focuses on cost efficiency (Hallgren and Olhager, 2009). Thus the study proposes the following two hypotheses:

Hypothesis 2-1: Low product variety is associated with increased focus on cost leadership.

Hypothesis 2-2: Cost efficiency is associated with increased focus on cost leadership.

Business performance is measured through accounting data that represents the company's performance and market valuation (Vickery et al., 2003) such as return on 
assets (ROA), return on investment (ROI) and return on sales (ROS). Tan et al. (1999) recommended nine diverse measures of business performance that involve market share, ROA and overall competitive position (market share growth, sales growth, ROA growth, production cost, customer service levels, product quality and competitive position). Vickery et al. (1999) supported the use of ROI, ROS, market share and the performance growth of each (e.g. market share growth) for business performance. Panayides (2007) argued that multiple measures of performance would reflect a firm's improvements more accurately. Thus, this study employed ROI, ROS, market share growth and sales growth to indicate business performance.

Product variety incurs cost increase in SC mainly due to the increased complexity in manufacturing, purchasing and logistics functions in SC. Also, trade-off exists between product variety and SC performance while a relationship between product variety and business performance is still arguable. Kekre and Srinivasan (1990) investigated the market benefits and cost disadvantages of product variety and concluded that product variety increases market share and a firm's profitability. To improve profitability, firms should make competitive moves, and new product introductions (NPI) are one of these moves that might positively influence market share and returns (Otero-Neira et al., 2010). However, in the case of mature firms, increased variety may not increase total demand that improves profitability. Instead, firms can increase variety to retain market share by a differentiation approach. Besides cost increases, an extensive array of options can at first seem highly appealing to consumers, yet can reduce their motivation to purchase the product. To address this variety issue, appropriate strategic approaches are crucial to achieve better business performance. Thus, the study proposes the following hypotheses based on the structural equation model (Figure 2): 
Hypothesis 3: Differentiation and cost efficiency are associated with business performance.

Hypothesis 4: Differentiation and cost leadership mediate the relationship between product variety and better business performance.

Different location and country characteristics affect the overall performance of a firm differently, and the level of internationalisation of each country may impact on economic performance (Antonio et al., 2012). As well as to confirm the findings, the study applies a comparative analysis to the cases of the UK and Korea, considering the different strategic focus of companies in each country and business performance measured according to the level of product variety.

\section{Figure 2. Structural equation model}

\section{Research methodology}

A questionnaire considering the product variety issues was sent to companies identified as manufacturers, based on their standard industrial classification (SIC) code. The data was collected from two countries with the intention of conducting a cross-examination and comparison. The survey was conducted by post with a package including a covering letter and return stamped envelope for the UK companies. In Korea, in order to obtain an acceptable level of response, email and direct interview surveys were chosen. 212 companies responded to the survey from the UK and 152 from Korea (total $=364$ ), yielding an acceptable 18\% overall response rate (see Frohlich 2002; Anseel et al., 2010). As a whole, $84.1 \%$ of the participants had positions above assistant manager and sales representative. $59.1 \%$ of the firms were small or medium-sized (SMEs) and the remaining 
40.9\% were large firms (LEs). Table 2 presents the industry types of the survey respondents. The demographic analysis of the responses indicated that the participating firms spanned a diverse group of manufacturing industries, which allowed for generalisation of the findings (Gatignon and Xuereb, 1997). Product variety was measured as fundamental, intermediate and peripheral using a 5-point scale $(1=1-5,2=6-10,3=11$ $15,4=16-20,5=$ above 20) based on the core product family (MacDuffie et al., 1996). Also, strategies including differentiation, cost leadership, cost efficiency, SC agility and business performance were measured using a 5-point Likert scale ( $1=$ poor, $5=$ excellent). Questions of cost leadership, differentiation and business performance compared to the company's competitors were asked.

\section{Table 2. Industry analysis}

The study sample was examined to determine whether non-respondent manufacturers differed significantly from those responding regarding key characteristics (i.e. sales and

number of employees), as suggested by Armstrong and Overton (1977), Gerbing and Anderson (1988) and Wiengarten et al. (2012) to check the existence of non-response bias. The result revealed that the sample did not suggest the presence of non-response bias. In addition, a measurement invariance test was applied since samples were taken randomly from the UK and South Korea, to identify the critical assumption that the basic structure of the model is stable across cultures, and that individuals in different countries use its scale in a similar manner (Turker, 2009; Malham and Saucier, 2014). Thus, through multi-group confirmatory factor analyses (CFA) the results of fit indexes suggest that measurement invariance is supported across the two countries $(\chi 2 / \mathrm{df}=2.09, \mathrm{RMSEA}=0.054, \mathrm{SRMR}=$ 0.606, CIF $=0.903)$. For common method bias, Harman's one-factor test was conducted 
using all variables. Since no single factor was apparent in the un-rotated factor structure, common method variance does not exist.

\section{Results}

\subsection{Reliability and validity}

Both exploratory factor analysis (EFA) and confirmatory factor analysis (CFA) were conducted using AMOS 22 to examine reliability and validity since items were collected from different studies. First, all constructs were assessed with CFA and the measurement model offered a satisfactory fit $\left(\chi^{2}[213]=347.507, \mathrm{GFI}=0.925\right.$, SRMR $=0.037, \mathrm{RMSEA}=$ $0.042, \mathrm{CFI}=0.965)$ with acceptable factor loadings $(>0.59)$. Composite reliability $(\mathrm{CR})$ also presented internal consistency $(\mathrm{CR}>0.754)$. Convergent validity was confirmed as all factor loadings exceeded 0.5 , as well as acceptable average variance extracted (AVE > 0.506). Table 3 indicates the result of CFA indicators. In addition, there is no case where the square of the correlation between a pair of constructs is greater than the AVE of the constructs. Thus, discriminant validity using the procedures suggested by Fornell and Larcker (1981) was confirmed (see Table 4).

Table 3. Confirmatory factor analysis

\section{Table 4. Inter-construct correlation estimates and related AVEs}

Second, Cronbach's alpha was tested to measure the reliability of the scale items before the EFA. The results yielded acceptable alpha values (Nunnally, 1978) and six structures showed acceptable internal consistency (>0.795). EFA was then applied to check construct validity (McDonald, 1981; Hattie, 1985). Six factors were extracted with eigenvalues greater than 1 , and six structures explained $68.0 \%$ of the total variance and all of the 
loadings above the minimum cut-off, 0.5 (Hair et al., 2010). EFA results showed all items with a high within-factor loading (i.e. convergent validity) and a low cross-factor loading (i.e. discriminant validity). The results of separate EFAs for both the UK and Korea also showed acceptable reliability and validity with the same items loaded. Thus, the variables of the construct have a consistent and stable structure across the groups (Floyd and Widaman, 1995). EFA and CFA confirmed the stability of all constructs for SEM and ttest. Table 5 presents the EFA pattern matrix.

\section{Table 5. Exploratory factor analysis}

\subsection{Structural equation modelling}

To test our proposed theoretical and empirical model, structural equation modelling (SEM) analysis was conducted. The result from samples shows that increased product variety and SC agility improve differentiation, while a decrease in product variety and an increase in cost efficiency improve cost leadership; thus hypotheses 1 (1-1 \& 1-2) and 2 (2-1 \& 2-2) are accepted. Also, business performance is associated with cost leadership and differentiation that mediates the relationship between product variety and business performance. Therefore, hypotheses 3 and 4 are accepted. Table 6 indicates the results of the structural equation modelling. Both high product variety and SC agility have a significant impact on the differentiation at 0.001 and 0.01 levels respectively. In addition, low product variety and cost efficiency are significantly related to cost leadership at 0.05 and 0.001 levels respectively. Product variety did not impact directly on business performance $(\mathrm{p}=0.557)$; instead, cost leadership and differentiation mediate the relationships at 0.05 and 0.001 levels respectively. 


\section{Table 6. Results of Structural Equation Modelling}

\subsection{Comparison between UK and Korea}

To test the research findings through a cross-examination a t-test was conducted. Regarding business strategies, cost leadership ( $\mathrm{p}<0.01)$ and differentiation $(\mathrm{p}<0.1)$ varied significantly between the two countries. In the case of performance measures, SC agility ( $p$ $<0.001)$, SC cost efficiency $(\mathrm{p}<0.01)$ and business performance $(\mathrm{p}<0.05)$ showed significant differences. With regard to mean value, the UK (mean $=3.51$ ) exhibited a sharper focus on differentiation than Korea $($ mean $=3.36)$, while Korea $($ mean $=3.42)$ focused more on cost leadership than the UK (mean $=3.18$ ). In addition, Korea scored better on cost efficiency than the UK. However, Korea $($ mean $=3.39)$ exhibited superior SC agility to the UK (mean $=3.11)$. Lastly, the UK (mean $=3.70)$ had better business performance than Korea (mean $=3.52$ ). The results imply that the UK focuses on a higher level of product variety and differentiation strategy (see Stavrulaki and Davis, 2010), which leads to superior business performance compared with Korea. Korea focuses more on cost leadership with lower-level product variety, which leads to higher cost efficiency. Table 7 explains the comparison of t-tests between the two countries.

\section{Table 7. T-test of structures by country}

\section{Discussion}

The study demonstrated the alignment of business strategy between product variety and SC through SEM analysis. The test justifies the appropriate business strategy according to companies' level of product variety and matching SC focus. A high product-variety policy is matched with agile SC as a differentiation strategy, while a low product-variety policy 
matches lean SC as a cost leadership strategy. High product variety with efficient SC can follow a 'mass customisation' strategy (e.g. automobile and computer industries such as BMW and Dell) while low product variety with an agile SC can be regarded as a 'hybrid' strategy (e.g. perishable food and electronic components industries such as Aldi and Intel). Therefore, the survey results support the concept that companies employing differentiation strategies by providing different product variety focus more on SC agility, customer service and relationship, which results in a high margin. Companies employing a cost leadership strategy with low product variety ensure SC efficiency through economy of scale, which leads to cost reduction.

However, product variety does not always guarantee improved business performance ( $\mathrm{p}$ $=0.557)$. Given the cost burden from the provision of product variety, companies should link their strategic alignment and capabilities with either SC agility or cost efficiency. Thus, decisions on differentiation, cost leadership or hybrid strategies can be considered based on the existing level of product variety and/or intention of new product introduction as well as SC capability supported. Especially business strategies such as differentiation and cost leadership significantly mediate the relationship between product variety and business performance. Any mismatched alignment cannot achieve the better business performance. The perception that product variety has the potential to positively influence market share and returns (Otero-Neira et al., 2010) is supported only through appropriate and matching business strategies (i.e. mediating factor). The results also support that an agile system is matched with differentiation, while cost efficiency is matched with a costleadership strategy (Hallgren and Olhager, 2009). At the functional level, the cost burden can be minimised by use of advanced technologies and appropriate strategies such as modularity, cellular manufacturing, information technology, postponement and SC integration strategies. 
The study extends the concept to the national level to justify the implications of the research findings. The UK shows higher levels of variety, differentiation and business performance while Korea exhibits higher performance in cost efficiency, cost leadership and SC agility, as supported by Stavrulaki and Davis (2010) and Agarwal et al. (2013). Higher levels of the production-dominant variety (i.e. increased production cost outweighs increased market mediation cost) are positively related with high-volume production (Randall and Ulrich, 2001). Thus, Korea appears to focus more on scale-efficient production (e.g. production-dominant variety) with a lower level of product variety than the UK, which has unstable demand due to greater product variety. However, it is notable that Korea has higher SC agility performance than the UK, which runs counter to the expectation that the higher the level of product variety the higher the level of agility. One explanation is Korea's high dependence on exports and manufacturing-based industry, as supported by Antonio et al.'s (2012) research. Supply chain activities for a quick response (i.e. agility) as a form of distinctive competence enable firms to achieve competitive export advantages (Piercy et al., 1998). Also, SC agility is a critical factor affecting overall global competitiveness (Swafford et al., 2006), especially for an export-based country. Christopher et al. (2006) concluded that agility and responsiveness are increasingly fundamental to competitive success in global business activity, such as global sourcing, offshore manufacturing and export. Thus, a global SC should be sufficiently agile to allow firms to improve their business performance and manage demand and supply uncertainty by being more responsive to unexpected change. Thus, a country concentrating on export competitiveness must achieve a global SC network structure with a high level of agility. For example, the total annual volume of exports in Korea (US\$ 527 billion) is lower than for the UK (US\$ 674 billion); however, export dependability accounted for a higher 
percentage of the GDP in Korea (36\%) as compared to the UK (23\%) in 2015 (International Monetary Fund, 2016; Central Intelligence Agency, 2016).

At the organisational level, the proximity of production facilities to the target market also enhances SC agility (Lee, 2004). Thus, companies that have a high level of product variety require careful consideration of their focus on local production and distribution to improve SC agility as well as variety management strategies such as modularity and postponement for cost reduction. In addition, better logistics performance can boost SC agility (see Arivis et al., 2012). Nowadays, the dominant trend in manufacturing industry is not towards pure customisation or pure standardisation, but towards the middle position of customer involvement (Lampel and Mintzberg, 1996), which is mass customisation. Thus, manufacturers that provide a low level of product variety may consider a structural shift to mass customisation in order to benefit from their SC agility capability. However, the movement should match the SC strategy and be supported by variety management activities.

\section{Conclusions}

The study investigated the relationships between product variety, SC and business strategies to improve business performance. First, the study demonstrated the importance of strategic alignment between product variety and SC focus, and suggested a theoretical justification for the choice of business strategies through the proposed model. A high level of product variety matches agile SC, while low product variety is aligned with SC cost efficiency. However, the level of product variety improves business performance only through matching business strategies such as cost leadership and differentiation. Therefore, an appropriate business strategy, considering the level of product variety and matching SC strategy, achieves the better business performance. Second, the overall comparison 
between the two countries found manufacturers in the UK demonstrating higher levels of product variety and differentiation (see Stavrulaki and Davis, 2010; Agarwal et al., 2013) than manufacturers in Korea. Instead, Korea displayed higher cost leadership attributes and cost efficiency than the UK. However, Korea shows better agile SC performance than the UK, which indicates the potential to increase product variety without incurring a significant cost burden.

This research makes several contributions. For theoretical implications, confirmative and exploratory factor analyses formed the concepts of each structure. Then, structural equation modelling confirmed the strategic relations between product variety and SC focus to improve business performance. Also, the comparison between manufacturers in the UK and Korea supports the fact that a high product-variety context focuses more on differentiation while a low product-variety context focuses on cost efficiency and cost leadership (Stavrulaki and Davis, 2010; Agarwal et al., 2013). Regarding practical contributions, the findings suggest manufacturers appropriate SC strategies based on the existing level of product variety in order to achieve competitive advantage. Such insight is particularly valuable for manufacturing concerns that are considering changing the heterogeneity of their product base through increased product variety for better business performance.

There are several limitations associated with this research. First, it investigated exclusively manufacturing industries in the UK and Korea. This particularity may limit the generalisability of the findings to other populations with different competitive, environmental, economic and cultural characteristics (Hughes and Morgan, 2008; Antonio et al., 2012). In addition, the growth and development of SCs is not driven only by internal motives, but also by a number of external factors, such as increasing globalisation, reduced barriers to international trade, advances in information technology, environmental 
concerns and government regulations (Gunasekaran et al., 2004). An appropriate topic for future research concerns the practical approach for multinational corporations to cope with variety and global SC issues without sacrificing costs. 


\section{References}

Agarwal, A., Shankar, R. and Tiwari, M. K. (2006), "Modeling the Metrics of Lean, Agile and Leagile Supply Chain: An ANP-based Approach", European Journal of Operational Research, Vol. 173 No. 1, pp. 211-225.

Anderson, C. (2006), The Long Tail: Why the Future of Business is Selling Less of More, Hyperion Press, New York, NY.

Anseel, F., Lievens, F., Schollaert, E. and Choragwicka, B. (2010), "Response Rate in Organisational Science, 1995-2008: A Meta-analytic Review and Guidelines for Survey Researchers", Journal of Business Psychology, Vol. 25 No. 3, pp. 335-349.

Antonio, M., Luciana, D.V. and Alfredo, D. (2015), "Internationalisation, cultural distance and country characteristics: A bayesian analysis of SMEs finalcial perfomance", Journal of Business Economics and Management, Vol. 16 No. 2, pp. 307-324.

Arvis, J. F., Mustra, M. A., Ojala, L., Shepherd, B. and Saslavsky, D. (2012), Connecting to Compete: Trade Logistics in the Global Economy, World Bank, Washington, D.C.

Beamon, B.M. (1999), "Measuring Supply Chain Performance", International Journal of Operations \& Production Management, Vol. 19 No. 3/4, pp. 275-292.

Berry, W.L. and Cooper, M.C. (1999), "Manufacturing Flexibility: Methods for Measuring the Impact of Product Variety on Performance in Process Industries", Journal of Operations Management, Vol. 17 No. 2, pp. 163-178.

Blecker, T. and Abdelkafi, N. (2006), "Complexity and Variety in Mass Customisation Systems: Analysis and Recommendations", Management Decision, Vol. 44 No. 7, pp. 908-929.

Caridi, M., Pero, M. and Sianesi, A. (2012), "Linking Product Modularity and Innovativeness to Supply Chain Management in the Italian Furniture Industry", International Journal of Production Economics, Vol 136 No. 1, pp. 207-217.

Central Intelligence Agency (2016), "The World Factbook", available at: https://www.cia.gov/library/publications/the-world-factbook/index.html (assessed 20 July 2016).

Child, P., Diederichs, R., Sanders, F.H. and Wisniowski, S. (1991), "SMR Forum: The Management of Complexity", Sloan Management Review, Vol. 33 No. 1, pp. 7380.

Christopher, M., Peck, H. and Towill, D. (2006), "A Taxonomy for Selecting Global Supply Chain Strategies", International Journal of Logistics Management, Vol. 17 No. 2, pp. 277-287.

Cousins, P.D., Lawson, B., Petersen, K.J. and Handfield, R.B. (2011), "Breakthrough Scanning, Supplier Knowledge Exchange, and New Product Development Performance", Journal of Product Innovation Management, Vol. 28 No. 6, pp. 930942.

Duray, R., Ward, P. T., Milligan, G. W. and Berry, W. L. (2000), "Approaches to Mass Customisation: Configurations and Empirical Validation", Journal of Operations Management, Vol. 18, pp. 605-625.

ElMaraghy, H., Schuh, G., ElMaraghy, W., Piller, F., Schonsleben, P., Tseng, M., and Benard, A. (2013), "Product Variety Management", CIRP Annals - Manufacturing Technology, Vol. 62 No. 2, pp. 629-652.

Fisher, M.L. (1997), "What is the Right Supply Chain for Your Product?", Harvard Business Review, Vol. 75 No. 2, pp. 105-116. 
Fisher, M., Ramdas, K. and Ulrich, K. (1999), "Component Sharing in the Management of Product Variety: A Study of Automotive Braking Systems", Management Science, Vol. 45 No. 3, pp. 297-315.

Fisher, M. L. and Ittner, C. D. (1999), "The Impact of Product Variety on Automobile Assembly Operations: Empirical Evidence and Simulation Analysis", Management Science, Vol. 45 No. 6, pp. 771-786.

Floyd, F.J. and Widaman, K.F. (1995), "Factor Analysis in the Development and Refinement of Clinical Assessment Instruments", Psychological Assessment, Vol. 7 No. 3, pp. 286-299.

Forza, C. and Salvador, F. (2002), "Managing for Variety in the Order Acquisition and Fulfilment Process: The Contribution of Product Configuration Systems", International Journal of Production Economics, Vol. 76 No. 1, pp. 87-98.

Fornell, C., Larcker, D.F. (1981), "Evaluating Structural Equation Models with Unobservable Variables and Measurement Error", Journal of Marketing Research, Vol. 18 No. 1, pp. 39-50.

Frohlich, M. T. (2002), "Methodological note: Techniques for Improving Response Rates in OM Survey Research", Journal of Operations Management, Vol. 20 No. 1, pp. 53-62.

Gatignon, H. and Xuereb, J.M. (1997), "Strategic Orientation of the Firm and New Product Performance", Journal of Marketing Research, Vol. 34 No. 1, pp. 77-90.

Gerbing, D. W. and Anderson, J. C. (1988), "An Updated Paradigm for Scale Development Incorporating Unidimensionality and Its Assessment", Journal of Marketing Research, Vol. 25 No. 2, pp. 186-192.

Gopal, P.R.C. and Thakkar, J. (2012), “A Review on Supply Chain Performance Measures and Metrics: 2000-2011", International Journal of Productivity and Performance Management, Vol. 61 No. 5, pp. 518-547.

Gunasekaran, A., Patel, C. and McGaughey, R.E. (2004), "A Framework for Supply Chain Performance Measurement", International Journal of Production Economics, Vol. 87 No. 3, pp. 333-347.

Hair, F.J., Black, W.C., Babin, B.J. and Anderson, R.E. (2010), Multivariate Data Analysis: A Global Perspective, Pearson Education, New Jersey.

Hallgren, M. and Olhager, J. (2009), "Lean and Agile Manufacturing: External and Internal Drivers and Performance Outcomes", International Journal of Operations \& Production Management, Vol. 29 No. 10, pp. 976-999.

Hattie, J. A. (1985), "Methodology Review: Assessing Unidimensionality of Tests and Items", Applied Psychological Measurement, Vol. 9 No. 2, pp. 139-164.

Holweg, M. and Pil, F.K. (2004), The Second Century: Reconnecting Customer and Value Chain through Build-to-Order: Moving beyond Mass and Lean Production in the Auto Industry, MIT Press, Cambridge, London.

Holweg, M and Helo, P. (2014), "Defining Value Chain Archtectures: Linking Strategic Value Creation to Operational Supply Chain Design", International Journal of Production Economics, Vol. 147, pp. 230-238.

Hu, S. J., Ko, J., Weyand, L., ElMaraghy, H. A., Lien, T. K., Koren, Y., Bley, H., Chryssolouris, G., Nasr, N. and Shpitalni, M. (2011), "Assembly System Design and Operations for Product Variety”, Annals- Cirp, Vol. 60 No. 2, pp. 715-733.

Hughes, P. and Morgan, R. E. (2008), "Fitting Strategic Resources With Product-Market Strategy: Performance Implications", Journal of Business Research Policy, Vol. 61 No. 4, pp. 323-331.

International Monetary Fund (2016), "Data and Statistics", available at: http://www.imf.org/external/data.htm (assessed 20 July 2016). 
Jeong, J.S. and Hong, P. (2007), "Customer Orientation and Performance Outcomes in Supply Chain Management", Journal of Enterprise Information Management, Vol. 20 No. 5, pp. 578-594.

Kim, S.W. (2006), "Effects of Supply Chain Management Practices, Integration and Competition Capability on Performance", Supply Chain Management, Vol. 11 No.3, pp. 241-248.

Kekre, S. and Srinivasan, K. (1990), "Broader Product Line: A Necessity to Achieve Success?”, Management Science, Vol. 36 No. 10, pp. 1216-1231.

Lampel, J. and Mintzberg, H. (1996), "Customising Customisation", Sloan Management Review, Vol. 38 No. 1, pp. 21-30.

Lancaster, K. (1990), "The Economics of Product Variety: A Survey", Marking Science, Vol. 9 No. 3, pp. 189-206.

Lee, H. L. (2002), "Aligning Supply Chain Strategies with Product Uncertainties", California Management Review, Vol. 44 No. 3, pp. 105-119.

Lee, H. L. (2004), “The Triple - A Supply Chain”, Harvard Business Review, Vol. 82 No. 10, pp. 102-112.

Lusch, R.F., Vargo, S.L. and O'Brien, M. (2007), "Competing Through Service: Insights from Service Dominant Logic", Journal of Retailing, Vol. 83 No. 1, pp. 5-18.

MacDuffie, J. P., Sethuraman, K. and M. L. Fisher, M. L. (1996), "Product Variety and Manufacturing Performance: Evidence from the International Automotive Assembly Plant Study", Management Science, Vol. 42 No. 3, pp. 350-369.

McDonald, R. P. (1981), "The Dimensionality of Tests and Items", British Journal of Mathematical and Statistical Psychology, Vol. 34 No. 1, pp. 100-117.

Malham, P.B. and Saucier, G. (2014), "Measurement Invariance of Social Axioms in 23 Countries", Journal of Cross-Cultural Psychology, Vol. 45 No. 7, pp. 1046-1060.

Michel, S., Brown, S.W. and Gallan, A.S. (2008), "An Expanded and Strategic View of Discontinuous Innovations: Deploying a Service-Dominant Logic", Journal of the Academy of Marketing Science, Vol. 36 No. 1, pp. 54-66.

Nunnally, J.C. (1978), Psychometric Theory, 2nd ed., McGraw-Hill, New York.

Otero-Neira, C., Varela, J. and Garcia, T. (2010), "Competitive Reaction to the Introduction of a New Product: An Exploratory Market Signalling Study", Journal of Strategic Marketing, Vol. 18 No. 5, pp. 379-394.

Panayides, P.M. (2007), "The Impact of Organizational Learning on Relationship Orientation, Logistics Service Effectiveness and Performance", Industrial Marketing Management, Vol. 36 No. 1, pp. 68-80.

Patel, P.C. and Jayaram, J. (2013), "The Antecedents and Consequences of Product Variety in New Ventures: An Empirical Study", Journal of Operations Management, Vol. 32 No. 1/2, pp. 34-50.

Piercy, N.F., Kaleka, A., and Katsikeas, C.S. (1998), "Sources of Competitive Advantage in High Performing Exporting Companies", Journal of World Business, Vol. 33 No. 4, pp. 378-393.

Porter, M.E. (2004), Competitive Advantage: Creating and Sustaining Superior Performance, Free Press, New York.

Randall, T. and Ulrich, K. (2001), "Product Variety, Supply Chain Structure, and Firm Performance: Analysis of the U. S. Bicycle Industry", Management Science, Vol. 47 No. 12, pp. 1588-1604.

Ranganathan, C., Dhaliwal, J.S. and Teo, T.S.H. (2004), "Assimilation and Diffusion of Web Technologies in Supply-Chain Management: An Examination of Key Drivers and Performance Impacts", International Journal of Electronic Commerce, Vol. 9 No. 1, pp. 127-161. 
Rosenzweig, E.D., Roth, A.V. and Dean Jr, J.W. (2003), “The Influence of An Integration Strategy on Competitive Capabilities and Business Performance: An Exploratory Study of Consumer Products Manufacturers", Journal of Operations Management, Vol. 21 No. 4, pp. 437-456.

Power, D.J., Sohal, A.S. and Rahman, S.U. (2001), "Critical Success Factors in Agile Supply Chain Management: An Empirical Study", International Journal of Physical Distribution and Logistic Management, Vol. 31 No. 4, pp. 247-265.

Qiu, L and Zhou, W. (2013), "Multyproduct Firms and Scope Adjustment in Globalisation", Journal of International Economics, Vol. 91, pp. 142-153.

Scavarda, L. F., Reichhart, A., Hamacher, S. and Holweg, M. (2010), "Managing Product Variety in Emerging Markets", International Journal of Operations \& Production Management, Vol. 30, No. 2, pp. 205-224.

Silveira, G., Da (1998), "A Framework for the Management of Product Variety", International Journal of Operations \& Production Management, Vol. 18 No. 3, pp. 271-285.

Stablein, T., Holweg, M. and Miemczyk, J. (2011), “Theoretical Versus Actual Product Variety: How Much Customisation do Customers Really Demand?", International Journal of Operations \& Production Management, Vol. 31 No. 3, pp. 350-370.

Stavrulaki, E. and Davis, M. (2010), "Aligning Products with Supply Chain Processes and Strategy”, International Journal of Logistics Management, Vol. 21 No. 1, pp. 127151.

Suarez, F.F., Cusumano, M.A. and Fine, C.H. (1996), "An Empirical Study of Manufacturing Flexibility in Printed Circuit Board Assembly", Operations Research, Vol. 44, pp. 223-240.

Swafford, P.M., Ghosh, S. and Murthy, N. (2006), "The Antecedents of Supply Chain Agility of a Firm: Scale Development and Model Testing", Journal of Operations Management, Vol. 24 No. 2, pp. 170-188.

Swafford, P.M., Ghosh, S. and Murthy, N. (2008), "Achieving Supply Chain Agility through its Integration and Flexibility", International Journal of Production Economics, Vol. 116, pp. 288-297.

Tan, K.C. and Kannan, V.R. (1998), "Supply Chain Management: Supplier Performance and Firm Performance", International Journal of Purchasing \& Materials Management, Vol. 34 No. 3, pp. 2-9.

Tan, K.C., Kannan, V.R., Handfield, R.B. and Ghosh, S. (1999), "Supply Chain Management: An Empirical Study of its Impact on Performance", International Journal of Operations \& Production Management, Vol. 19 No. 9-10, pp. 10341052.

Theodore, P.S., Daniel, A.P., Joonhwan, I., Diane, A.M. and John, E.B. (2017), "New Frontiers in Logistics Research: Theorizing at the Middle Range", Journal of Business Logistics, Vol. 38 No. 1, pp. 6-17.

Thonemann, U. W. and Bradley, J. R. (2002), "The Effect of Product Variety on SupplyChain Performance", European Journal of Operational Research, Vol. 143 No. 3, pp. 548-569.

Tracey, M. and Tan, C.L. (2001), "Empirical Analysis of Supplier Selection and Involvement, Customer Satisfaction, and Firm Performance", Supply Chain Management - An International Journal, Vol. 6 No. 4, pp. 174-188.

Treville, S.D., Shapiro, R.D. and Hameri, A.P. (2004), "From Supply Chain to Demand Chain: The Role of Lead Time Reduction in Improving Demand Chain Performance", Journal of Operations Management, Vol. 21 No. 6, pp. 613-627. 
Tummala, V.M.R., Phillips, C.L.M. and Johnson, M. (2006), "Assessing Supply Chain Management Success Factors: A Case Study", Supply Chain Management - An International Journal, Vol. 11 No. 2, pp. 179-192.

Turker, D. (2009), "Measuring Corporate Social Responsibility: A Scale Development Study”, Journal of Business Ethics, Vol. 85 No. 4, pp. 411-427.

Um, J., Lyons, A., Lam, H. K.S., Cheng, T. C. E. and Dominguez, P. C. (2017), "Product Variety Management \& Supply Chain Performance: A Capability Perspective on Understanding Relationships \& Impact", International Journal of Production Economics, Vol. 187, pp. 15-26.

Um, J. (2017), "Improving Supply Chain Flexibility and Agility through Variety Management", International Journal of Logistics Management, Vol. 28 No. 2, pp. 464-487.

Vickery, S.K., Calantone, R. and Dröge, C. (1999), "Supply Chain Flexibility: An Empirical Study", Journal of Supply Chain Management, Vol. 35 No. 3, pp. 16-24.

Vickery, S.K., Jayaram, J., Droge, C. and Calantone, R. (2003), "The Effects of an Integrative Supply Chain Strategy on Customer Service and Financial Performance: An Analysis of Direct Versus Indirect Relationships", Journal of Operations Management, Vol. 21 No. 5, pp. 523-539.

Wan, X., Evers, P.T. and Dresner, M.E. (2012), "Too Much of a Good Thing: The Impact of Product Variety on Operations and Sales Performance", Journal of Operations Management, Vol. 30 No. 4, pp. 316-324.

Wang, Y. and Feng, H. (2012), "Customer Relationship Management Capability: Measurement, Antecedents and Consequences", Management Decision, Vol. 50 No. 1, pp. 115-129.

Wiengarten, F., Pagell, M. and Fynes, B. (2012), "Supply Chain Environmental Investments in Dynamic Industries: Comparing Investment and Performance Differences with Static Industries, International Journal of Production Economics, Vol. 135 No. 2, pp. 541-551.

Yeh, K. H. and Chu, C. H. (1991), "Adaptive Strategies for Coping with Product Variety Decisions", International Journal of Operations \& Production Management, Vol. 11 No. 8, pp. 35-47.

Zokaei, K. and Hines, P. (2007), "Achieving Consumer Focus in Supply Chains", International Journal of Physical Distribution \& Logistics Management, Vol. 37 No. 3, pp. 223-247.

Zhou, W. and Duan, W. (2012), "Online User Reviews, Product Variety, and the Long Tail: An Empirical Investigation on Online Software Downloads", Electronic Commerce Research and Applications, Vol. 11 No. 3, pp. 275-289. 
Table 1. Characteristics of product variety in supply chain

\begin{tabular}{lcc}
\hline Product Variety & Low & High \\
\hline Demand Uncertainty & Predictable & Unpredictable \\
Production Focus & Economy of scale & Diseconomy of scale \\
Level of customisation & Low customisation & High customisation \\
Production structure & Make to stock & Make / assembly to order \\
Product life cycle & Long & Short \\
Product type & Functional & Innovative \\
Relationship focus & Suppliers & Customers \\
Supply chain strategy & Lean SC & Agile SC \\
Market strategy & Cost leadership & Differentiation \\
Supply chain focus & Cost & Customer service \\
Profit margin & Low & High \\
\hline
\end{tabular}

Source: Adapted from Fisher et al. (1977), Stavrulaki and Davis (2010)

Table 2. Industry analysis

\begin{tabular}{lcccc}
\multicolumn{1}{c}{ Characteristics } & UK & \multicolumn{2}{c}{ Korea } \\
& Frequency & Percentage & Frequency & Percentage \\
\hline Manufacturing industry type & & & & \\
Food, beverage, tobacco & 17 & 8.0 & 9 & 5.9 \\
Wood and furniture & 21 & 9.9 & 11 & 7.2 \\
Chemical materials and products & 15 & 7.1 & 13 & 8.6 \\
Non-metal mineral products & 10 & 4.7 & 5 & 3.3 \\
Fabricated metal products & 29 & 13.7 & 4 & 2.6 \\
Computer and communication products & 9 & 4.2 & 17 & 11.2 \\
Electronic parts and components & 19 & 9.0 & 22 & 14.5 \\
Electrical machinery and equipment & 18 & 8.5 & 21 & 13.8 \\
Transport equipment & 23 & 10.8 & 15 & 9.9 \\
Textiles and leather & 5 & 2.4 & 3 & 2.0 \\
Paper products & 3 & 1.4 & 8 & 5.3 \\
Machinery and equipment & 23 & 10.8 & 10 & 6.6 \\
Basic metal products & 5 & 2.4 & 3 & 2.0 \\
Clothing and footwear & 5 & 2.4 & 6 & 3.9 \\
Other & 10 & 4.7 & 5 & 3.3 \\
Total & 212 & & 152 & \\
\hline
\end{tabular}

Table 3. Confirmatory factor analysis

\begin{tabular}{|c|c|c|c|c|c|}
\hline Structure & Code & Abbreviated item statement & $\begin{array}{c}\text { Factor } \\
\text { loading }\end{array}$ & $\mathrm{CR}$ & AVE \\
\hline \multirow{3}{*}{ Product Variety } & $\mathrm{P} 1$ & Different core models and designs & 0.789 & \multirow{3}{*}{0.754} & \multirow{3}{*}{0.506} \\
\hline & $\mathrm{P} 2$ & Different technical options dependent on core design & 0.862 & & \\
\hline & P3 & $\begin{array}{l}\text { Particular options and accessories independent of core } \\
\text { design }\end{array}$ & 0.837 & & \\
\hline \multirow{7}{*}{$\begin{array}{l}\text { Supply chain } \\
\text { agility (AG) }\end{array}$} & AG1 & Ability to rapidly reduce product development cycle time & 0.674 & \multirow{7}{*}{0.870} & \multirow{7}{*}{0.570} \\
\hline & $\mathrm{AG} 2$ & Ability to rapidly reduce lead time & 0.740 & & \\
\hline & AG3 & Ability to rapidly increase the level of product customization & 0.720 & & \\
\hline & AG4 & Ability to rapidly improve level of customer service & 0.727 & & \\
\hline & AG5 & Ability to rapidly improve delivery reliability & 0.761 & & \\
\hline & AG6 & $\begin{array}{l}\text { Ability to rapidly improve responsiveness to changing } \\
\text { market needs }\end{array}$ & 0.763 & & \\
\hline & AG7 & Ability to rapidly reduce delivery lead time & 0.758 & & \\
\hline \multirow{2}{*}{$\begin{array}{c}\text { SC Cost } \\
\text { efficiency (CE) }\end{array}$} & CE1 & Ability to minimize total cost of resources used & 0.760 & \multirow[b]{2}{*}{0.865} & \multirow[b]{2}{*}{0.617} \\
\hline & CE2 & $\begin{array}{l}\text { Ability to minimize total cost of distribution } \\
\text { (including transportation and handling costs) }\end{array}$ & 0.716 & & \\
\hline
\end{tabular}




\begin{tabular}{|c|c|c|c|c|c|}
\hline & CE3 & $\begin{array}{l}\text { Ability to minimize total cost of manufacturing } \\
\text { (including labour, maintenance, and re-work costs) }\end{array}$ & 0.714 & & \\
\hline & CE4 & Ability to minimize total inventory holding costs & 0.626 & \multirow{3}{*}{0.913} & \multirow{3}{*}{0.760} \\
\hline \multirow{3}{*}{ Cost leadership } & CL1 & Reduce manufacturing unit cost & 0.866 & & \\
\hline & CL2 & Supply low product price & 0.780 & & \\
\hline & D1 & $\begin{array}{l}\text { Customer service differentiation (deliver a high quality } \\
\text { product with volume flexibility and agility) }\end{array}$ & 0.767 & \multirow{3}{*}{0.835} & \multirow{3}{*}{0.630} \\
\hline \multirow[t]{2}{*}{ Differentiation } & D2 & $\begin{array}{l}\text { Technology differentiation (develop a new product quickly } \\
\text { with design flexibility depending on demand) }\end{array}$ & 0.769 & & \\
\hline & D3 & $\begin{array}{l}\text { Marketing differentiation (control the sales and distribution } \\
\text { network with a distinctive brand image) }\end{array}$ & 0.586 & & \\
\hline \multirow{4}{*}{$\begin{array}{l}\text { Business } \\
\text { Performance }\end{array}$} & BP1 & Return on sales & 0.590 & \multirow{4}{*}{0.873} & \multirow{4}{*}{0.637} \\
\hline & BP2 & Return on assets & 0.632 & & \\
\hline & BP3 & Market share growth & 0.790 & & \\
\hline & BP4 & Sales growth & 0.854 & & \\
\hline
\end{tabular}

Table 4. Inter-construct correlation estimates and related AVEs

\begin{tabular}{|c|c|c|c|c|c|c|}
\hline & PV & $\mathrm{AG}$ & $\mathrm{CE}$ & CL & $\mathrm{D}$ & BP \\
\hline $\mathrm{PV}$ & $0.506^{+}$ & & & & & \\
\hline AG & $.155^{* *}$ & $0.570+$ & & & & \\
\hline $\mathrm{CE}$ & .056 & $.386^{* *}$ & $0617+$ & & & \\
\hline $\mathrm{CL}$ & -.062 & $292 * *$ & $.499 * *$ & $0.760+$ & & \\
\hline D & $.231 * *$ & $.531 * *$ & $.385^{* *}$ & $.282 * *$ & $0.630+$ & \\
\hline BP & $.140 * *$ & $.298 * *$ & $.415^{* *}$ & $.211 * *$ & $419 * *$ & $0.637+$ \\
\hline Mean & 3.44 & 3.23 & 3.40 & 3.28 & 3.45 & 3.63 \\
\hline SD & 1.31 & 0.74 & 0.62 & 0.75 & 0.73 & 0.65 \\
\hline
\end{tabular}

$+=$ Average variance extracted, $*$ represents significant at the 0.05 level and $* * 0.01$ level.

Table 5. Exploratory factor analysis

\begin{tabular}{lcccccc}
\hline Items & 1 & 2 & 3 & 4 & 5 & 6 \\
\hline & $\alpha=0.806$ & $\alpha=0.835$ & $\alpha=0.795$ & $\alpha=0.868$ & $\alpha=0.835$ & $\alpha=0.835$ \\
\hline AG1 & .755 & .065 & .063 & .046 & .076 & .129 \\
AG2 & .776 & .067 & .168 & .016 & .102 & .156 \\
AG3 & .760 & .028 & .037 & .130 & .168 & .031 \\
AG4 & .708 & .156 & .111 & .059 & .178 & .002 \\
AG5 & .758 & .111 & .120 & -.056 & .149 & .065 \\
AG6 & .753 & .103 & .188 & .084 & .152 & -.081 \\
AG7 & .767 & .072 & .142 & .037 & .061 & .123 \\
BP 1 & .118 & .744 & .197 & -.052 & .218 & .014 \\
BP 2 & .069 & .811 & .170 & -.083 & .158 & -.011 \\
BP 3 & .124 & .764 & .100 & .168 & .087 & .124 \\
BP 4 & .143 & .811 & .147 & .165 & .014 & .044 \\
CE1 & .176 & .128 & .762 & .014 & .035 & .220 \\
CE2 & .175 & .181 & .705 & .016 & .072 & .198 \\
CE3 & .138 & .118 & .787 & .038 & .128 & .076 \\
CE4 & .136 & .182 & .685 & -.015 & .138 & .085 \\
PV1 & .057 & .090 & .052 & .862 & .085 & -.033 \\
PV2 & .049 & .053 & -.019 & .895 & .066 & -.008 \\
PV3 & .103 & .017 & .004 & .872 & .084 & -.061 \\
D 1 & .283 & .195 & .102 & .129 & .750 & .099 \\
D 2 & .389 & .223 & .142 & .104 & .630 & .045 \\
D 3 & .172 & .102 & .147 & .076 & .763 & .086 \\
CL 1 & .129 & .063 & .321 & -.079 & .105 & .816 \\
CL 2 & .154 & .077 & .226 & -.041 & .099 & .865 \\
\hline
\end{tabular}


Table 6. Results of structural equation modelling

\begin{tabular}{lccc}
\hline Construct & Path coefficient & t-value & Significance \\
\hline 1. Differentiation & & & \\
SC Agility & $+.530^{* * *}$ & 8.086 & .000 \\
Product Variety & $+.076^{* *}$ & 3.238 & .001 \\
2. Cost Leadership & & & \\
SC Cost Efficiency & $+.765^{* * *}$ & 9.749 & .000 \\
Product Variety & $-.065^{*}$ & -2.234 & .025 \\
3. Business Performance & & & .000 \\
Differentiation & $+.527^{* * *}$ & 5.826 & .557 \\
Product Variety & +.016 & .558 & .018 \\
Cost Leadership & $+.133^{*}$ & 2.373 & \\
\hline
\end{tabular}

$\chi^{2}[221]=182.119 ; \mathrm{GFI}=0.898 ; \mathrm{CFI}=0.932 ; \mathrm{NNFI}=0.922 ; \mathrm{RMAEA}=0.057 ; \mathrm{SRMR}=0.065$

$* \mathrm{p}<0.05 ; * * \mathrm{p}<0.01 ; * * * \mathrm{p}<0.001$

Table 7. T-test of structures by country

\begin{tabular}{lccccc}
\hline \multirow{2}{*}{ Dependent Variable } & \multicolumn{5}{c}{ Mean } \\
\cline { 2 - 6 } & UK & Korea & Total & T & Significance \\
\hline Product variety & 3.74 & 3.04 & 3.44 & $5.195^{* * *}$ & .000 \\
SC Agility & 3.11 & 3.39 & 3.23 & $-3.581^{* * *}$ & .000 \\
SC Cost efficiency & 3.31 & 3.52 & 3.40 & $-2.963 * *$ & .003 \\
Cost leadership & 3.18 & 3.42 & 3.28 & $-3.156^{* *}$ & .002 \\
Differentiation & 3.51 & 3.36 & 3.45 & $1.858^{+}$ & .064 \\
Business performance & 3.70 & 3.52 & 3.63 & $2.591^{*}$ & .010 \\
\hline
\end{tabular}

${ }^{+}$represents significant level $\mathrm{p}<0.1, * \mathrm{p}<0.05, * * \mathrm{p}<0.01, * * * \mathrm{p}<0.001$ 
Figure 1. Strategic alignment model with product variety in SC

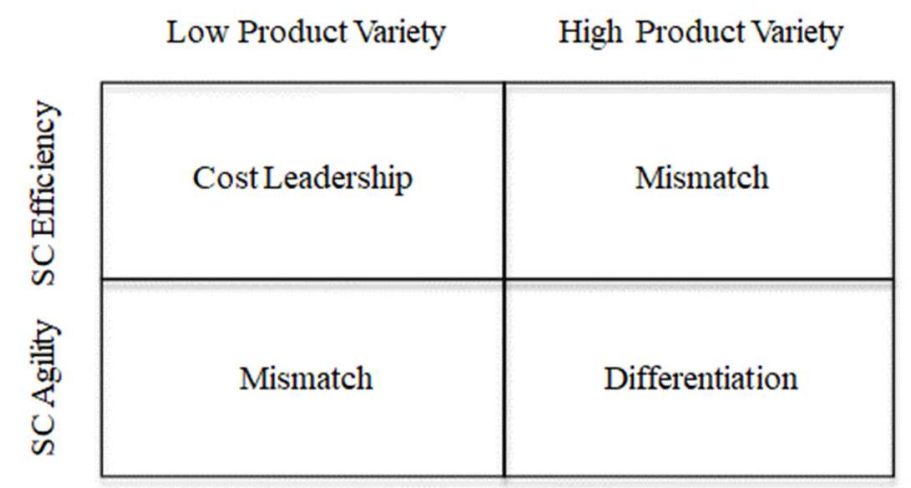

Figure 2. Structural equation model

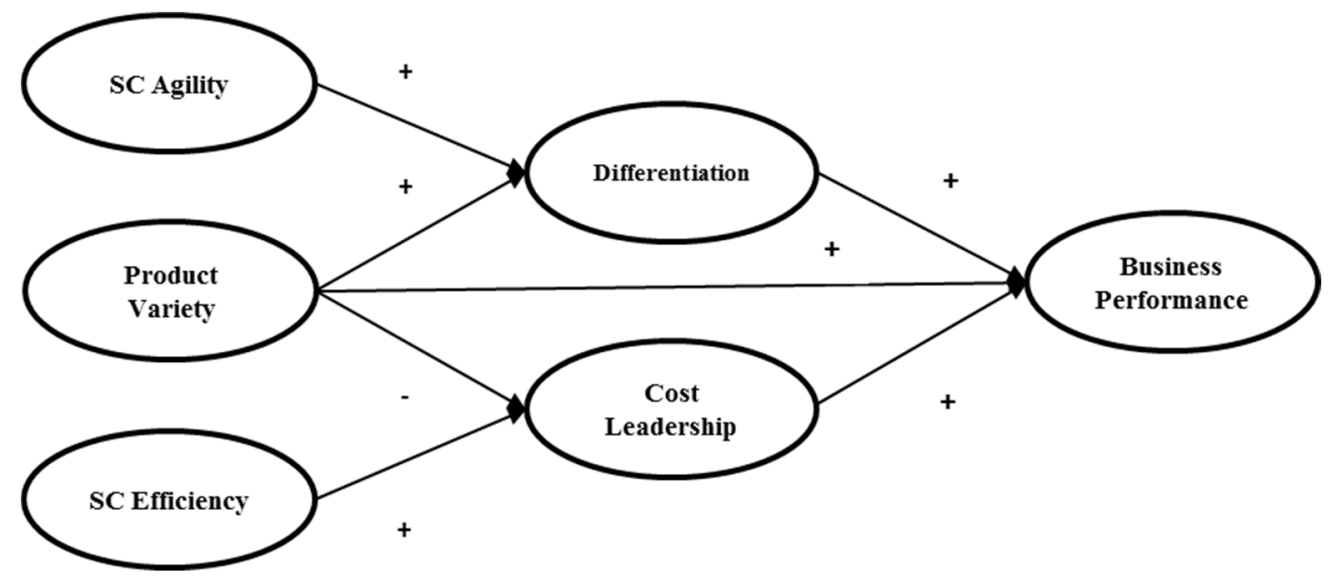

